\title{
KINERJA KEUANGAN PERUSAHAAN DAERAH SEBELUM DAN SESUDAH MERGER
}

\author{
Agung Prajanto \\ agungpraja12@gmail.com \\ Jurusan Manajemen Universitas Dian Nuswantoro Semarang, Indonesia
}

\section{Info Artikel \\ Sejarah Artikel: \\ Diterima : Juni 2019 \\ Disetujui : Juli 2019 \\ Dipublikasikan : Agustus 2019}

Keywords:

Mergers;Financial

Performance;Regional

Companies

\begin{abstract}
Abstrak
Perusahaan Daerah Badan Kredit Kecamatan (PD. BKK) merupakan salah satu badan usaha milik pemerintah provinsi jawa tengah yang menjadi sumber pendapatan asli daerah. Keberadaan PD. BKK membantu perekonomian masyarakat di Jawa tengah dalam bentuk simpanan dan penyaluran pinjaman untuk kegiatan usaha. Jumlah unit PD BKK yang banyak membuat tata kelola manajemen dan pengendalian internal tidak bisa berjalan dengan maksimal seperti banyak terjadi kredit bermasalah penyelewengan dana dan sebagainya. Salah satu upaya untuk meminimalkan permasalahan internal tersebut adalah dengan merger. Perda No. 4 tahun 2017 tentang Pembentukan PD BPR BKK Jawa tengah menjadi awal pelaksanaan merger PD BKK Jateng. Hasil analisis sebelum merger menunjukkan bahwa kinerja perusahaan yang dilihat dari rasio keuangan menunjukkan beberapa rasio keuangan hasil yang tidak bisa mencapai nilai maksimal seperti ROA dan CAR hal ini disebabkan oleh adanya kerugian dan belum adanya permodalan dari pemrov jateng. Setelah dilakukan merger, kinerja keuangan mendapatkan hasil yang berbeda pada tahun 2018. Hal ini ditunjukkan dengan Rasio ROA dan CAR yang semakin meningkat dikarenakan adanya beberapa penghapusan beberapa kredit/aset bermasalah dan adanya tambahan setoran modal dari pemrov.
\end{abstract}

REGIONAL FINANCIAL PERFORMANCE OF THE COMPANY BEFORE AND AFTER MERGER

\section{Abstract}

Perusahaan Daerah Badan Kredit Kecamatan (PD. BKK) is one of the business entities owned by the Central Java provincial government which is a source of local revenue. The existence of PD. BKK helps the economy of the people in Central Java in the form of deposits and lending for business activities. The large number of $P D B K K$ units that make management governance and internal control unable to run optimally as many credit problems occur are misappropriation of funds and so on. One effort to minimize these internal problems is by merger. Perda No. 4 of 2017 concerning the Establishment of PD BPR BKK Java is the beginning of the implementation of the merger of PD BKK Central Java. The results of the analysis before the merger show that the company's performance seen from financial ratios shows some of the results of financial ratios that cannot reach maximum values such as ROA and CAR due to the existence of losses and the lack of capital from the Central Java provincial government. After a merger, financial performance gets different results in 2018. This is indicated by the increasing ROA and CAR ratio due to the elimination of several credit / problem assets and additional capital deposits from the provincial government.

\begin{tabular}{lr}
\hline Alamat korespondensi : Jl Nakula I No. 5-11 Semarang & ISSN \\
E-mail: agungpraja12@gmail.com & $1979-4800$ (cetak) \\
& $2580-8451$ (online)
\end{tabular}




\section{PENDAHULUAN}

Pendapatan Asli Daerah (PAD) merupakan aspek serius yang perlu diperhatikan dan dikelola oleh pemerintah daerah. Sebagai sumber keuangan yang terbesar, penerimaan dari PAD harus dikelola dengan baik untuk seiring dengan pelaksanaan otonomi daerah. PAD merupakan hal penting bagi daerah karena menunjukkan potensi kemandirian suatu daerah dalam mengelola keuangan daerah. Bentuk PAD berasal dari retribusi, pajak daerah, hasil pengelolaan kekayaan daerah yang dipisahkan dan lain-lain PAD yang sah. Penerimaan PAD yang berasal dari hasil pengelolaan kekayaan daerah yang dipisahkan adalah pendapatan yang berasal dari Perusahaan Daerah (PD) atau Badan Usaha Milik Daerah (BUMD).

Sejarah terbentuknya BUMD sudah berlangsung lama sejak disahkannya UU No. 5 Tahun 1962 tentang Perusahaan Daerah kemudian diperkuat dengan UU No. 5 tahun 1974 tentang pokok-pokok Pemerintah Daerah. Tujuan dibentuknya BUMD adalah untuk melaksanakan pembangunan daerah melalui pelayanan jasa kepada masyarakat, penyelenggaraan kemanfaatan umum dan peningkatan penghasilan pemerintah daerah. Lebih lanjut berdasarkan sasarannya terdapat dua jenis Perusahaan Daerah yaitu perusahaan untuk kepentingan umum dan perusahaan daerah untuk tujuan peningkatan penerimaan daerah dalam peningkatan PAD. Bidang usaha yang dijalankan BUMD terdiri dari bidang jasa keuangan dan perbankan (BPD/Bank Pembangunan Daerah, Bapas/Bank Pasar, BKK/Badan Kredit Kecamatan), jasa air bersih (Perusahaan Daerah Air Minum/PDAM) dan aneka usaha produktif seperti percetakan, perdagangan, perkebunan, dan lain-lain.

Propinsi Jawa Tengah (Jateng) mempunyai beberapa potensi penerimaan PAD dari BUMD yang berupa kontribusi setoran deviden atau pajak. Tantangan untuk meningkatkan potensi PAD Jateng salah satunya adalah dengan meningkatkan peran serta BUMD. BUMD Sektor jasa keuangan seperti Bank Pembangunan Daerah (BPD) Bank Pasar (Bapas) dan Badan Kredit Kecamatan (BKK) selalu didorong untuk meningkatkan PAD Propinsi Jateng melalui deviden. Realisasi deviden BUMD di Jateng mencapai 441,3 Miliar atau mencapai 96,28\% dari target APBD 2018. Artinya dalam pelaksanaan APBD Jateng 2018, beberapa BUMD telah mencapai target $100 \%$. Salah satu BUMD tersebut adalah PD BPR BKK yang mampu merealisasikan 61,69 atau $89,41 \%$ dari target APBD.

Deviden yang direalisasikan oleh PD BPR BKK merupakan penggabungan dari PD BKK yang sudah berstatus Bank Perkreditan Rakyat (BPR) dan yang masih bersatus PD BKK. Agar potensi capaian deviden meningkat setiap tahunnya perlu dilakukan upaya peningkatan kinerja dari BUMD. Salah satunya adalah dengan mengubah peningkatan status PD BKK menjadi PD BPR BKK. Propinsi Jateng telah memiliki 37 unit PD BPR BKK, hasil penggabungan 510 unit PD BKK seluruh kecamatan di Jateng. Namun masih ada 29 unit PD BKK di beberapa Kecamatan yang belum melakukan merger sampai dengan tahun 2010.

Pengubahan status PD BKK menjadi PD BPR BKK telah dituangkan dalam Peraturan Otoritas Jasa Keuangan No 20/POJK.03/2014 tentang BPR, atas POJK tersebut Pemerintah Propinsi Jateng dituntut untuk segera melakukan merger 29 unit PD BKK yang belum berstatus PD BPR BKK. Hal ini perlu diupayakan guna meningkatkan kinerja, penyehatan kesehatan dan perbaikan manajemen ke 29 PD BKK tersebut. Selain itu juga bahwa pelaksanaan merger tersebut bertujuan untuk meningkatkan peran 
dan fungsi PD BKK agar dapat mendorong pertumbuhan ekonomi, peningkatan pelayanan kepada masyarakat khususnya penyedia modal usaha bagi usaha mikro, kecil dan menengah serta sebagai salah satu sumber pendapatan daerah. Atas POJK tersebut, Pemerintah Propinsi Jateng menanggapinya dengan menerbitkan Perda No 4 tahun 2017 tentang Pembentukan Perusahaan Perseroan Daerah Bank Perkreditan Rakyat Badan Kredit Kecamatan Jawa Tengah. (PD BPR BKK Jateng).

Salah satu alasan merger ke 29 PD BKK tersebut adalah bertujuan untuk penyehatan kinerja keuangan. Sejak merger PD BKK terakhir tahun 2010, ke 29 PD BKK yang tersisa dan belum melakukan merger mengalami beberapa permasalahan kinerja keuangan yang berimbas pada kasus hukum dan kerugian negara dengan jumlah yang sangat banyak. Akibatnya jumlah deviden yang diterima dari PD BKK yang belum merger tersebut menjadi tidak maksimal. Oleh karena sebagai upaya penyehatan dan penataan manajemen ke 29 PD BKK tersebut melakukan merger menjadi PD BPR BKK Jateng.

Permasalahan PD BKK sebelum melakukan merger sangat banyak seperti kredit macet, kredit fiktif, pencurian aset, korupsi simpanan dana masyarakat dan kasus kecurangan yang lain sehingga berdampak pada tingkat kesehatan PD BKK. Aspek kinerja keuangan seperti rasio permodalan, rasio profitabilitas dan likuiditas menjadi rasio keuangan yang terkena dampak signifikan atas kecurangan tersebut. Keadaan tersebut mendorong Pemerintah Propinsi Jateng untuk mengambil kebijakan merger.

Meningkatkan nilai dan kinerja dari sebuah perusahaan merupakan salah satu tujuan dari merger, sebagaimana hasil penelitian yang dilakukan oleh Widjanarko (2009) mengungkapkan bahwa tidak ada perbedaan yang signifikan kinerja perusahaan untuk 2 tahun sebelum dan sesudah merger dan akuisisi. Berbeda dengan penelitian Payamta dan Setiawan (2004) yang menunjukkan hasil bahwa merger tidak menghasilkan sinergi perusahaan.

Berdasarkan uraian permasalahan diatas maka penulis mencoba untuk melakukan kajian secara deskriptif tentang dampak merger terhadap kinerja perusahaan dengan studi kasus merger PD. BKK Jateng. Penelitian ini dimaksudkan untuk mengetahui perubahan kinerja keuangan entitas dalam hal ini PD. BKK Jateng setelah dilakukan merger sesuai dengan Perda No. 4 tahun 2017 tentang Pembentukan PD BPR BKK Jateng.

\section{TELAAH PUSTAKA \\ Sejarah PD BKK}

PD BKK Berdiri pada tahun 1969 berdasarkan Surat Keputusan Gubernur No.Psa.5226/1969/8/2/4. BKK berdiri di tiap-tiap kecamatan di seluruh Jawa Tengah dengan status sebagai proyek. Kemudian pada tahun 1981, kedudukan BKK makin kokoh dengan dikeluarkannya Perda Jateng No.11/1981. Perda ini telah diubah selama beberapa kali seiring berjalannya waktu. Perda Jateng yang saat ini digunakan adalah Perda No.11/2002.

Pada tahun 1983, dikeluarkan pula Paket Juni 1983 tentang Deregulasi Perbankan di Indonesia. Paket ini bertujuan untuk merangsang pertumbuhan sektor perbankan di Indonesia. Paket kemudian diperbaharui kembali melalui Pakto (Paket Oktober) 1988. Isi dari Paket Oktober 1988 ini tentang dorongan terhadap pendirian bank-bank dan bertujuan untuk memberikan pelayanan jasa keuangan. Pemerintah juga 
mengeluarkan kebijakan Deregulasi Perbankan dengan adanya kemudahan menjadi BPR (Bank Perkreditan Rakyat).

Tahun 1991 menjadi awal mula berkembangnya BKK, karena pada saat itu Pemerintah mengusulkan 510 unit BKK untuk diubah statusnya menjadi BPR. Namun hanya 202 unit BKK yang disetujui oleh BI dan diubah statusnya menjadi BPR BKK. Sebanyak 308 unit lainnya masih berstatus BKK. Selang 4 tahun kemudian tepatnya di tahun 1995 Pemerintah kembali mengusulkan 308 unit BKK kepada BI agar diubah statusnya menjadi BPR BKK. Hasilnya 148 unit disetujui menjadi BPR BKK dan 160 unit sisanya masih tetap sebagai BKK.

Untuk memperluas unit kerjanya BKK ditiap Kabupaten atau Kota melakukan merger. Tepatnya pada tahun 2005-2008 PD BPR BKK yang berjumlah 350 diseluruh Jawa Tengah merger menjadi berjumlah 37 unit. Selanjutnya pada jangka waktu tahun 2009-2010 PD BKK yang berjumlah 160 unit di tiap Kabupaten atau Kotanya merger menjadi 29 unit.

Sampai dengan tahun 2010, dari 510 unit PD BKK di seluruh kecamatan di Jateng yang sudah mengubah statusnya dan merger menjadi PD BPR BKK berjumlah 37 unit. Jumlah tersebut belum secara keseluruhan masih ada 29 unit PD BKK yang belum melakukan merger. Ke 29 PD BKK tersebut adalah PD BKK Eromoko Kabupaten Wonogiri, PD BKK Karanganyar Kabupaten karanganyar, PD BKK Klaten Kabupaten Klaten, PD BKK Sukoharjo Kabupaten Sukoharjo, PD BKK Tanon Kabupaten Sragen, PD BKK Kertek Kabupaten Wonosobo, PD BKK Tayu Kabupaten Pati, PD BKK Pekalongan Utara Kota Pekalongan, PD BKK Pemalang Kabupaten Pemalang, PD BKK Susukan Kabupaten Semarang, PD BKK Pringsurat Kabupaten Temanggung, PD BKK Kendal Kota Kabupaten Kendal, PD BKK Kaliori Kabupaten Rembang, PD BKK Mojosongo Kabupaten Boyolali, PD BKK Karangmoncol Kabupaten Purbalingga, PD BKK Banjarnegara Kabupaten Banjarnegara, PD BKK Kesugihan Kabupaten Cilacap, PD BKK Purwokerto Selatan Kabupaten Banyumas, PD BKK Tempuran Kabupaten Magelang, PD BKK Sruweng Kabupaten Kebumen, PD BKK Butuh Kabupaten Purworejo, PD BKK Brebes Kabupaten Brebes, PD BKK Sidorejo Kota Salatiga, PD BKK Dempet Kabupaten Demak, PD BKK Bandar Kabupaten Batang, dan PD BKK Kajen Kabupaten Pekalongan.

Beberapa permasalahan yang timbul masalah seperti kinerja keuangan, manajemen dan kelangsungan usaha dari PD BKK tersebut membuat Pemerintah Provinsi Jateng menerbitkan Perda No 4 tahun 2017 tentang Pembentukan Perusahaan Perseoran Daerah Bank Perkreditan Rakyat Badan Kredit Kecamatan Jawa Tengah. (PD BPR BKK Jateng)

Pembentukan ke 29 PD BKK untuk merger menjadi PD BPR BKK Jateng didasarkan atas adanya Peraturan Otoritas Jasa Keuangan No 20/POJK.03/2014 tentang BPR, bahwa PD BKK Jateng telah memenuhi syarat untuk bertransformasi menjadi BPR. Selain itu juga bahwa pelaksanaan merger ini dalam rangka meningkatkan peran dan fungsi PD BKK agar dapat mendorong pertumbuhan ekonomi, peningkatan pelayanan kepada masyarakat khususnya penyedia modal usaha bagi usaha mikro, kecil dan menengah serta sebagai salah satu sumber pendapatan daerah. Oleh karena itu PD BKK perlu dilakukan penyehatan, penguatan dan peningkatan kinerja dengan sistem merger. 


\section{Asas, Maksud dan Tujuan didirikannya PD BKK}

Sesuai dengan Perda Propinsi Jateng No 19 tahun 2002, PD BKK dalam melakukan usahanya berasaskan Demokrasi Ekonomi dengan prinsip kehati-hatian. PD BKK dibentuk dengan maksud dan tujuan untuk mendorong pertumbuhan perekonomian dan Pembangunan Daerah di segala bidang serta dalam rangka meningkatkan taraf hidup rakyat sebagai salah satu sumber pendapatan daerah.

\section{Fungsi, tugas dan usaha}

PD BKK berfungsi sebagai salah satu lembaga intermediasi di bidang keuangan dengan tugas menjalankan usaha sebagai Lembaga Kredit Mikro sesuai dengan Peraturan Perundang Undangan yang berlaku. Sedangkan tugas dari PD BKK antara lain

- Merupakan ekonomi kerakyatan

- Membantu menyediakan modal usaha bagi usaha mikro, kecil dan menengah

- Memberikan pelayanan modal dengan cara mudah, murah dan mengarah dalam mengembangkan kesempatan berusaha

\section{Pengertian Merger}

Menurut Undang- undang dan Peraturan Pemerintah: UU No . 40/2007 Pasal 1 angka 9: Merger adalah perbuatan hukum yang dilakukan oleh 1 (satu) perseroan atau lebih untuk menggabungkan diri dengan perseroan lain yang telah ada mengakibatkan aktiva dan pasiva dari perseroan yang menggabungkan diri tersebut beralih karena hukum kepada perseroan yang menerima penggabungan dan selanjutnya status badan hukum perseroan yang menggabungkan diri tersebut berakhir karena hukum.

Dwi Martani (2017) menyatakan bahwa merger adalah kombinasi bisnis yang dilakukan dengan menggabungkan dua atau lebih entitas, dimana entitas yang diakuisisi dibubarkan serta semua aset dan liabilitasnya diambil alih pihak yang mengakuisisi. Dalam merger harus ada pihak yang dibubarkan dan pihak yang tetap berdiri untuk menerima aset dari pembubaran pihak yang dibubarkan. Bentuk ini sering juga disebut sebagai legal merger karena secara hukum entitas dibubarkan dan bergabung dengan perusahaan lain. Entitas yang masih berdiri akan menggabungkan aset dan liabilitasnya dengan aset dan liabilitas entitas yang diakuisisi.

\section{Manfaat Merger}

Menurut Syaichu (2006) merger memberikan beberapa tujuan dan keuntungan potensial selain meningkatkan kesejahteraan pemegang saham diantaranya adalah:

- Keuntungan sinergi sebagaimana yang dijelaskan The synergy hypothesis menunjukkan bahwa penggabungan mampu menciptakan keuntungan yang lebih besar jika entitas beroperasi sendiri.

- Keuntungan monolistik sebagaimana The Monopoly Hypothesis mengungkapkan bahwa dengan melakukan merger maka entitas akan mengalami peningkatan kekuatan pasar (market power) dalam menjalankan operasional bisnisnya

- Efisiensi Manajerial sebagaimana The Inefficiency Hypothesis menyimpulkan bahwa dengan buruknya kinerja manajemen sebelum melakukan merger maka dengan merger kinerja yang jelek mampu di kurangi dan efisiensi kinerja bisa dioptimalkan. 
- Entitas yang terpisah-pisah sebelum melakukan merger secara geografis bisa dioptimalkan dengan melakukan diversifikasi melalui merger. Realisasi keuntungan akan lebih cepat tercapai dengan melakukan diversifikasi geografis hasil merger.

\section{Kinerja Keuangan}

Pengertian kinerja menurut Sukhemi (2007) diartikan sebagai capaian yang diperoleh entitas dalam jangka waktu periode tertentu yang menggambarkan tingkat keberhasilan entitas tersebut. Kinerja keuangan menunjukkan kemampuan perusahaan untuk mengelola aset perusahaan. Kinerja sebuah entitas perbankan capaian keberhasilan sebuah entitas dalam bidang penyaluran dana dan penghimpunan dana.

\section{Pengertian dan Peran Bank Perkreditan Rakyat (BPR)}

Landasan Hukum BPR adalah UU No 7/1992 tentang perbankan sebagaimana telah diubah dengan UU No 10/1998. Dalam UU tersebut secara tegas disebutkan bahwa BPR adalah Bank yang melaksanakan kegiatan usaha secara konvensional atau berdasarkan prinsip syariah yang dalam kegiatannya tidak memberikan jasa dalam lalu lintas pembayaran. Bentuk hukum BPR dapat berupa Perseroan Terbatas (PT), Perusahaan Daerah (PD) atau Koperasi. Peran BPR diantaranya adalah:

- Menghimpun dana dari masyarakat dalam bentuk deposito berjangka dan tabungan dan atau bentuk lainnya yang dipersamakan dengan itu.

- Memberikan kredit pinjaman bagi pengusaha kecil dan atau masyarakat umum

- Menempatkan dananya dalam bentuk Sertifikat Deposito dan atau tabungan pada bank lain

\section{Rasio Pemodalan}

Menurut ketentuan Bank Indonesia, pengertian modal bank dibedakan antara pendirian bank yang berada di Indonesia dan kantor cabang asing yang menjalankan operasionalnya di Indonesia. Modal bank didirikan dan berkantor pusat di Indonesia yang terdiri atas modal inti atau primary capital dan modal pelengkap atau secondary capital (Lukman Dendawijaya :2003)

Risiko kerugian bank dan kemampuan bank dalam menjalankan usaha sangat ditentukan oleh rasio kecukupan modal. Oleh karena Proporsi penyediaan modal minimum dari keseluruhan total Aktiva Tertimbang Menurut Risiko (ATMR) yang dipersyaratkan oleh Otoritas Jasa Keuangan (OJK) harus selalu dipertahankan oleh sebuah bank agar tidak mengalami kekurangan modal.

Aspek penyediaan modal minimum ini didasarkan atas Rasio CAR (Capital Adequacy Ratio) yang telah ditetapkan oleh otoritas Bank Indonesia. Rasio CAR yang ditetapkan oleh Bank Indonesia minimal harus berada pada angka 8\%, bank yang memperoleh nilai CAR kurang dari $8 \%$ maka harus mendapatkan segera perhatian sendiri dari otoritas bank. Rasio CAR dalam penelitian ini dirumuskan dengan:

$$
\mathrm{CAR}=\frac{\text { Modal Bank }}{\text { ATMR }} \times 100 \%
$$

Sesuai dengan SK DIR BI Nomor: 30/21/KEP/DIR tanggal 30 April 1997 tentang tata cara penilaian tingkat kesehatan Bank, hasil penilaian aspek permodalan adalah sebagai berikut: 
Tabel 1.1

Kriteria Penilaian rasio CAR

\begin{tabular}{|l|c|}
\hline \multicolumn{1}{|c|}{ Kriteria } & Hasil Rasio CAR \\
\hline Sehat & $>8 \%$ \\
\hline Cukup Sehat & $7,99 \%-8 \%$ \\
\hline Kurang Sehat & $6,5 \%-7,99 \%$ \\
\hline Tidak Sehat & $<6,5 \%$ \\
\hline
\end{tabular}

Sumber: Kriteria Penilaian kesehatan bank

\section{Rasio Likuiditas}

Rasio likuiditas adalah menunjukkan kemampuan suatu entitas dalam memenuhi kewajiban jangka pendeknya pada saat jatuh tempo, (Prastowo, 2015). Suatu bank dapat dikatakan likuid, apabila bank bersangkutan mampu membayar semua hutangnya terutama hutang jangka pendek. Hutang jangka pendek lebih banyak berupa simpanan pihak ketiga seperti tabungan dan deposito.

Bank dikatakan likuid jika simpanan dana pihak ketiga mampu dikembalikan setiap saat maupun sesuai dengan jangka waktu yang telah ditentukan. Selain itu juga bank harus mampu menyeimbangkan simpanan dana pihak ketiga tersebut dengan penyaluran kredit kepada masyarakat. Oleh karena itu dalam penelitian ini rasio likuiditas diukur dengan menggunakan Cash Ratio (CR) dan Loan to Deposit (LDR)

CR merupakan perbandingan antara ance ancer dengan hutang ancer. Sedangkan LDR merupakan rasio yang mengukur perbandingan antara jumlah uang yang diterima dalam bentuk simpanan pihak ketiga dengan jumlah penyaluran dana dalam bentuk kredit kepada masyarakat.

$$
\begin{aligned}
& \text { Cash Rasio }=\frac{\text { Aset Lancar }}{\text { Hutang Lancar }} \times 100 \% \\
& \text { LDR }=\frac{\text { Kredit yang diberikan }}{\text { Dana yang diterima }} \times 100 \%
\end{aligned}
$$

Tabel 1.2

Kriteria Penilaian Aspek Likuiditas

\begin{tabular}{|l|c|c|}
\hline \multicolumn{1}{|c|}{ Kriteria } & Hasil Rasio CR & Hasil Rasio LDR \\
\hline Sehat & $>4,05 \%$ & $>94,75 \%$ \\
\hline Cukup Sehat & $>3,30 \%-<4,05 \%$ & $>94,75-<98,50 \%$ \\
\hline Kurang Sehat & $>2,55 \%-<3,30 \%$ & $>98,50 \%-<102,25 \%$ \\
\hline Tidak Sehat & $<2,55 \%$ & $>102,25 \%$ \\
\hline
\end{tabular}

\section{Sumber: Kriteria Penilaian kesehatan bank}

\section{Rasio Rentabilitas}

Analisis rasio rentabilitas bank adalah alat untuk menganalisis atau mengukur tingkat efisiensi usaha dan profitabilitas yang dicapai oleh bank yang bersangkutan. Rentabilitas merupakan kemampuan suatu entitas dalam menghasilkan laba selama periode tertentu. Rasio rentabilitas yang diukur dalam penelitian ini meliputi besarnya 
rasio laba sebelum pajak terhadap total aset (ROA), dan rasio beban operasional terhadap pendapatan operasional bank (BOPO).

$$
\begin{aligned}
\mathrm{ROA} & =\frac{\text { Laba bersih sebelum pajak }}{\text { total aset }} \times 100 \% \\
\mathrm{BOPO} & =\frac{\text { Total Beban Operasional }}{\text { Total Pendaptan Operasional }} \times 100 \%
\end{aligned}
$$

Tabel 1.3

Hasil Penilaian Aspek Rentabilitas

\begin{tabular}{|l|c|c|}
\hline \multicolumn{1}{|c|}{ Kriteria } & Hasil Rasio ROA & Hasil Rasio BOPO \\
\hline Sehat & $>1,215 \%$ & $>93,52 \%$ \\
\hline Cukup Sehat & $>0,99 \%->1,21 \%$ & $93,52 \%<\mathrm{x}<94,72 \%$ \\
\hline Kurang Sehat & $>0,76 \%-<0,99 \%$ & $94,72 \% \mathrm{x}<95,92 \%$ \\
\hline Tidak Sehat & $<0,76 \%$ & $>95,92 \%$ \\
\hline
\end{tabular}

Sumber: Kriteria Penilaian kesehatan bank

\section{METODE}

Penelitian ini menggunakan metode penelitian deskriptif. Metode penelitian ini menyelidiki keadaan atau kondisi lain yang sudah dipaparkan khususnya dalam laporan penelitian (Arikunto, 2010). Penelitian ini mengukur tingkat kesehatan PD. BKK Jateng sebelum dan setelah dilakukan merger oleh Pemerintah Provinsi Jawa Tengah sesuai dengan Perda No 4 tahun 2017 tentang Pembentukan Perusahaan PD. BKK Jawa Tengah. Objek penelitian yang digunakan adalah laporan keuangan konsolidasian PD. BKK tahun 2016 dan 2018. Tahun 2016-2018 digunakan sebagai objek penelitian dengan tujuan untuk mengetahui kinerja keuangan setahun dan sebelum dan sesudah merger.

\section{HASIL DAN PEMBAHASAN}

Ringkasan ikhtisar Laporan keuangan PD. BKK tahun 2016-2018 menunjukkan beberapa trend penurunan beberapa pos di neraca sebelum dan sesudah merger. Total aset secara berangsur mengalami penurunan di tahun 2017 sebesar $-8,49 \%$ dan tahun 2018 sebesar $-92,37 \%$. Salah satu syarat untuk melakukan merger yaitu dengan membersihkan beberapa kredit bermasalah yang ada di laporan keuangan. Hal tersebut membuat Langkah Pemrov Jateng untuk melakukan upaya penghapusan kredit. Seperti yang terlihat pada tabel bahwa penurunan total aset sejalan dengan penurunan kredit tahun 2017 dan 2018 sebesar -14,77\% dan -89,20\%.

Secara signifikan penurunan aset dan kredit tersebut terjadi setahun setelah merger yaitu di tahun 2018. Signifikannya penurunan di tahun 2018 tersebut menunjukkan bahwa beberapa kredit yang bermasalah telah dilakukan penghapusan dari laporan keuangan. Menurunnya jumlah kredit juga berpengaruh dengan turunnya penyisihan kerugian kredit yang dibentuk oleh PD. BKK Jateng dari sebelumnya turun 14,77\% di tahun 2017 menjadi turun secara signifikan sebesar -89,20\% di tahun 2018 . 
Penurunan tersebut sangat membantu pemulihan performa laporan keuangan pasca merger.

Selain penyaluran kredit, penempatan dana pihak ketiga juga mengalami penurunan sebesar $-11,10 \%$ tahun 2017 dan 92,09\% tahun 2018. Penurunan ini disebabkan oleh adanya beberapa pelunasan atau penarikan dana nasabah secara besar pada beberapa PD. BKK setelah dilakukan merger. Nasabah lebih mementingkan kehati-hatian atau memilih penempatan dana di lembaga keuangan lain dari pada menempatkan dana di PD. BKK. Selain itu juga untuk menghindari dana tidak dapat ditarik maka nasabah lebih memilih memindahkan deposito atau tabungan dipindahkan ke tempat lain.

Konversi permodalan Pemrov dan Pemkab dalam melakukan merger merupakan salah satu prosedur dalam melaksanakan merger. Dampak dari konversi modal membuat total modal mengalami penurunan sebesar $-89,64 \%$ pada tahun 2017 dan sebesar $-92,09 \%$. Hasil konversi modal mengubah komposisi modal disetor sehingga yang awalnya Pemrov dan Pemkab secara terpisah, setelah merger menjadi satu kesatuan modal saham.

Kemudian komponen permodalan yaitu saldo laba mengalami kenaikan sebesar 2,10\% dari tahun 2016 ke 2017 sebelum merger. Namun setelah merger menjadi turun secara signifikan sebesar -101,60. Penurunan ini lebih disebabkan oleh adanya performa laporan keuangan yang belum menutup kerugian tahun-tahun sebelumnya. Sebagai dampak penghapusan kredit membuat menjadikan sistem penyaluran kredit lebih selektif dilakukan. Selain itu juga penggunaan cadangan umum dan cadangan tujuan yang digunakan untuk menutup kerugian tahun lalu yang cukup signifikan membuat total modal menjadi turun. Secara lebih rinci dapat dilihat pada tabel 1.1 sebagai berikut:

Tabel 1.4

Ringkasan Laporan Keuangan Tahunan Konsolidasian PD. BKK Jateng tahun 2016-2018.

\begin{tabular}{|l|r|r|r|}
\hline \multicolumn{1}{|c|}{ Keterangan } & \multicolumn{1}{|c|}{$\mathbf{2 0 1 8}$} & \multicolumn{1}{c|}{$\mathbf{2 0 1 7}$} & \multicolumn{1}{c|}{$\mathbf{2 0 1 6}$} \\
\hline Total Aset & 89.165 .377 .573 & 1.167 .895 .538 .490 & 1.276 .275 .636 .923 \\
\hline & $-92,37 \%$ & $-8,49 \%$ & - \\
\hline $\begin{array}{l}\text { Kredit yang } \\
\text { diberikan }\end{array}$ & 63.446 .557 .660 & 762.759 .872 .688 & 882.227 .702 .730 \\
\hline & & & - \\
\hline Penempatan Dana & 78.357 .168 .591 & 991.090 .087 .781 & 1.114 .779 .103 .293 \\
\hline & $-92,09 \%$ & $-11,10 \%$ & - \\
\hline Penyisihan Kredit & 7.306 .206 .706 & 67.638 .862 .774 & 79.358 .370 .100 \\
\hline & $-89,20 \%$ & $-14,77 \%$ & - \\
\hline Total Modal & 14.682 .404 .525 & 141.660 .280 .451 & 137.878 .587 .133 \\
\hline & $-89,64 \%$ & $2,74 \%$ & - \\
\hline Saldo Laba (Rugi) & $(93.095 .477)$ & 5.833 .044 .068 & 5.712 .933 .551 \\
\hline & $-101,60 \%$ & $2,10 \%$ & - \\
\hline
\end{tabular}

Sumber: Laporan Keuangan PD. BKK Jateng 
Tabel 1.5

Hasil Analisis Rasio Permodalan

\begin{tabular}{|c|r|r|r|}
\hline Tahun & $\mathbf{2 0 1 8}$ & $\mathbf{2 0 1 7}$ & \multicolumn{1}{|c|}{$\mathbf{2 0 1 6}$} \\
\hline Hasil Rasio CAR & $23,27 \%$ & $18,69 \%$ & $15,55 \%$ \\
\hline Persentase Perubahan & $4,6 \%$ & $3,1 \%$ & $15,5 \%$ \\
\hline Kategori & Sehat & Sehat & Sehat \\
\hline
\end{tabular}

Sumber: data diolah

PD. BKK Jawa Tengah mengalami peningkatan yang baik dari segi rasio permodalan sebelum dan sesudah merger. Tahun 2016 sebelum dilakukan merger tingkat Rasio CAR adalah sebesar 15,5\% lebih rendah dari tahun 2017 saat dilakukan merger yaitu sebesar $18,69 \%$ meskipun rasio CAR adalah sehat secara angka. Rendahnya rasio CAR pada tahun 2016 disebabkan oleh jumlah rugi kumulatif yang masih tinggi.

Beberapa PD. BKK yang mengalami permasalahan kredit berimbas pada kerugian pada laporan keuangan khususnya laporan laba rugi. Masalah kredit macet, kredit fiktif dan kredit bermasalah lainnya.mengakibatkan PD. BKK harus membentuk beban penyisihan kerugian kredit yang cukup besar. Beban tersebut dapat menggerus pendapatan PD. BKK jika pendapatan yang diperoleh lebih kecil. Akibatnya PD. BKK yang mengalami kredit bermasalah akan memperoleh rugi yang cukup banyak.

Rasio permodalan yang rendah pada saat sebelum merger selain disebabkan oleh banyaknya kredit bermasalah pada beberapa PD. BKK juga disebabkan oleh adanya besarnya agunan yang diambil alih hasil dari kredit bermasalah tersebut. Agunan yang diambil alih sangat tinggi dipengaruhi juga oleh kredit bermasalah yang cukup tinggi. Nominal gabungan agunan dari beberapa PD. BKK berdampak pada pengurangan modal inti dari agunan tersebut akibatnya rasio CAR akan mengalami penurunan.

Rasio permodalan semakin meningkat/sehat pada tahun 2018 setahun setelah merger menjadi sebesar $23,27 \%$ atau naik $4,6 \%$. Kenaikan rasio modal/CAR tersebut disebabkan oleh terpulihkannya rugi kumulatif atau penurunan rugi kumulatif. Hal ini membuktikan bahwa manajemen PD. BKK lebih berhati-hati dan mampu pulih dari beberapa permasalahan kredit setelah dilakukan merger. Selesainya permasalahan kredit macet, penyelesaian agunan yang diambil alih, serta peningkatan laba membuat permodalan PD. BKK setelah merger menjadi sehat.

Faktor permodalan yang sehat pada saat setelah merger juga dipengaruhi oleh tambahan modal disetor dari Pemprov Jateng. Sejak dikeluarkannya Perda tentang merger PD. BKK menjadikan Pemprov dan Pemkab harus menyetorkan tambahan modal pada beberapa PD. BKK yang akan di lakukan merger pada tahun 2017. Komitmen modal tersebut harus dipenuhi oleh Pemprov dan Pemkab sebagai salah satu syarat penguatan modal pada PD. BKK yang akan demerger. 
Tabel 1.6

Hasil Analisis Rasio Likuiditas

\begin{tabular}{|c|r|r|r|}
\hline Tahun & $\mathbf{2 0 1 8}$ & $\mathbf{2 0 1 7}$ & $\mathbf{2 0 1 6}$ \\
\hline Hasil Rasio LDR & $80,94 \%$ & $76,96 \%$ & $79,14 \%$ \\
\hline Persentase perubahan & $4,0 \%$ & $-2,2 \%$ & $79,1 \%$ \\
\hline Kategori Rasio LDR & Sehat & Sehat & Sehat \\
\hline & & & $32,23 \%$ \\
\hline Hasil Rasio CR & $46,88 \%$ & $36,93 \%$ & $32,2 \%$ \\
\hline Persentase Perubahan & $10,0 \%$ & $4,7 \%$ & Sehat \\
\hline Kategori Rasio CR & Sehat & Sehat & \\
\hline
\end{tabular}

Sumber: data diolah

Likuiditas PD. BKK sebelum dilakukan merger adalah sehat dengan nilai CR yang semakin meningkat dengan kenaikan 4,7\% di tahun 2017 dan 10,0\% pada tahun 2018 setahun setelah merger. Hal ini menunjukkan bahwa dengan adanya merger pada tahun 2017, likuiditas PD. BKK Jateng secara konsolidasi semakin meningkat. Selain mendapatkan sumber dana dari Pemrov dan Pemkab, kenaikan likuiditas juga dikarenakan oleh jumlah kewajiban ias yang secara berangsur-angsur ias di tutup oleh jumlah ias ias yang semakin besar.

Selain dilihat dari rasio CR, likuiditas PD. BKK Jateng juga ias diukur dari rasio LDR. LDR menunjukkan seberapa besar perbandingan jumlah dana dengan jumlah kredit yang diberikan. Perkembangan rasio LDR dari tahun 2017 sampe 2018 menunjukkan kenaikan LDR sebesar 4,0\%. Besaran angka LDR 80,94\%pada tahun 2018 setelah merger menunjukkan keseimbangan antara jumlah kredit dan dana yang dihimpun masih seimbang.

Secara operasional bentuk usaha PD. BKK Jateng yang berupa lembaga keuangan masyarakat mengharuskan perusahaan melakukan kegiatan operasional simpanan dana dan penyaluran dana. Pada tahun 2016 sebelum merger PD. BKK Jateng menunjukkan kinerja LDR yang sehat dengan angka rasio 79,14\%. Pertumbuhan kredit dan pendanaan yang tinggi namun tidak diimbangi dengan tata kelola yang baik pada saat sebelum merger, memunculkan beberapa permasalahan pada. Meskipun secara rasio LDR adalah sehat namun kualitas kredit yang diberikan cenderung tidak sehat. Hal ini terlihat pada tingginya pembentukan penyisihan kerugian kredit yang besar pada yaitu Rp 79 Miliar di tahun 2016 dan Rp 67 Miliar di tahun 2017.

Seperti yang terlihat pada ias ikhtisar laporan keuangan, Jumlah kredit yang diberikan sebelum merger tahun 2016 adalah sebesar Rp 882 Miliar dan Jumlah Dana adalah Rp1.114 Miliar. Kredit yang tinggi tersebut masih mengandung beberapa potensi tidak dapat ditagih karena macet atau bermasalah sejalan dengan tingginya penyisihan kerugian kredit yang dibentuk. Namun pada tahun 2017 saat dilakukan merger dan 2018 setahun setelah merger, angka kredit turun sangat signifikan dari sebesar Rp 762 miliar Tahun 2017 menjadi 63 Miliar tahun 2018.

Sebagaimana komitmen Pemrov dan Pemkab yang harus dipenuhi sebelum PD. BKK melakukan merger adalah melakukan penghapusan beberapa kredit-kredit bermasalah yang ada di PD. BKK Jateng yang sudah tidak ias tertagih atau terselesaikan. Penghapusan tersebut dilakukan agar nantinya Laporan Keuangan PD. BKK Jateng hasil merger sudah terbebas dari masalah keuangan baik dari internal maupun eksternal. Serta dengan harapan bahwa merger adalah menutup laporan 
keuangan yang lama dengan laporan keuangan yang baru yang lebih sehat serta terbebas dari unsur pos keuangan yang tidak sehat.

Tabel 1.7

\section{Hasil Analisis Rasio Rentabilitas}

\begin{tabular}{|c|r|r|r|}
\hline Tahun & $\mathbf{2 0 1 8}$ & $\mathbf{2 0 1 7}$ & $\mathbf{2 0 1 6}$ \\
\hline Hasil Rasio ROA & $1,27 \%$ & $1,77 \%$ & $-1,70 \%$ \\
\hline Persentase Perubahan & $-0,5 \%$ & $3,5 \%$ & $-1,7 \%$ \\
\hline Kategori Rasio ROA & Sehat & Sehat & Tidak Sehat \\
\hline & & & \\
\hline Hasil Rasio BOPO & $89,33 \%$ & $82,82 \%$ & $84,51 \%$ \\
\hline Persentase Perubahan & $6,5 \%$ & $-1,7 \%$ & $84,5 \%$ \\
\hline Kategori Rasio BOPO & Sehat & Sehat & Sehat \\
\hline
\end{tabular}

Sumber: data diolah

Analisa Rasio rentabilitas PD. BKK sebelum merger pada tahun 2016 menunjukkan angka $-1,70 \%$ yang artinya adalah tidak sehat karena dibawah $1 \%$. Keadaan ini lebih disebabkan oleh adanya rugi pada tahun tersebut serta faktor besarnya total aset pada tahun 2016 sebelum merger. Hal ini menunjukkan bahwa tata kelola aset PD. BKK Jateng baik berupa aset lancar dan non lancar yang dimiliki baik sebelum merger belum baik dioptimalkan dalam memperoleh pendapatan. Total aset yang besar didominasi oleh besarnya jumlah kredit yang didiapat oleh PD. BKK Jateng dengan harapan untuk mendapatkan pemasukan yang maksimal dari pendapatan bunga kredit. Namun karena adanya kredit bermasalah dan macet yang ada pada kredit tersebut mengakibatkan potensi kredit yang besar itu tidak dapat dimaksimalkan menjadi pendapatan sehingga mengalami kerugian.

Adanya merger pada tahun 2017 oleh Pemprov Jateng cukup bisa memperbaiki kinerja rasio ROA pada tahun 2017. Rasio ROA mengalami trend yang positif ditahun 2017 sebesar $1,77 \%$ atau naik 3,5\% dari tahun 2016 yang sebelumnya mengalami ROA $-1,70 \%$. Keadaan ini menunjukkan bahwa setelah dilakukan merger, tingkat kesehatan aset PD. BKK Jateng menjadi terkelola dengan baik. Kredit atau penyaluran dana yang tidak membawa potensi untuk meningkatkan pendapatan perusahaan dilakukan penghapusan dari laporan keuangan. Seperti yang terlihat bahwa total aset pada tahun 2017 dan 2018 mengalami penurunan yang signifikan. Rasio ROA sedikit turun pada akhir tahun 2018 setelah merger dengan rasio $1,27 \%$ turun $0,5 \%$ dari tahun sebelumnya.

Lebih lanjut, pada rasio rentabilitas yang kedua adalah rasio BOPO yaitu membandingkan antara total beban operasional dengan pendapatan operasional. Sebelum dan sesudah dilakukan merger, tingkat kesehatan rasio BOPO adalah sehat dengan angka rasio dibawah 90,00\%. Salah satu keuntungan dari laporan konsolidasian ini adalah mampu meningkatkan pendapatan secara gabungan. Meskipun pada saat sebelum merger beberapa PD. BKK mengalami pendapatan yang minim karena beban yang terlalu banyak, mampu ditutup oleh PD BKK lain yang mendapatkan pendapatan tinggi dan beban sedikit. Sehingga secara konsolidasi antara beban operasional dan pendapatan operasional adalah seimbang antara PD BKK yang mengalami keuntungan dengan PD BKK yang mengalami kerugian. 


\section{PENUTUP}

Merger merupakan salah satu kombinasi bisnis dengan melakukan penggabungan dua atau lebih entitas dengan visi dan misi yang sama tanpa membubarkan entitas sebelumnya. Perda No 4 Tahun 2017 tentang pembentukan PD. BKK Jateng menunjukkan upaya Pemprov Jateng untuk mengefisiensikan pengawasan dan pembinaan PD. BKK Jateng. Selain itu juga sebagai untuk meningkatkan status dan kelangsungan usaha PD. BKK menjadi PD. BPR BKK Jateng dengan tujuan untuk mendapatkan pengawasan yang lebih optimal dari sebelumnya dari Pemrov Jateng saja, bisa meningkat menjadi pengawasan dari OJK Jateng.

Hasil analisa keuangan sebelum merger menunjukkan beberapa lemahnya pengendalian internal pada beberapa PD. BKK. Kredit bermasalah dan penyelewengan dana nasabah sebelum merger berdampak pada kesehatan laporan keuangan dan performa laba yang dihasilkan menjadi tidak sehat meskipun secara ukuran perusahaan adalah besar dari total asetnya. Selain itu juga lemahnya pengawasan dari pusat dan tidak adanya otoritas yang melakukan pengawasan langsung seperti OJK membuat kinerja PD. BKK Jateng sebelum merger menjadi kurang terkendali dalam hal penyaluran dana maupun penghimpunan dana.

Revitalisasi aspek manajemen dan aspek keuangan PD. BKK Jateng setelah merger seperti melakukan rotasi jabatan, penggantian manajer, penghapusan kredit bermasalah membuat performa serta kinerja laporan keuangan setelah merger mulai membaik terlihat dari performa rasio keuangan yang sehat. Turunnya angka kredit yang diberikan dan angka penyisihan kerugian kredit merupakan salah satu indikasi bahwa manajemen dalam hal ini Pemprov Jateng berkomitmen untuk menata ulang aspek manajerial dan aspek keuangan PD. BKK Jateng yang telah di merger agar tujuan dari merger bisa tercapai demi kelangsungan usaha entitas tersebut.

\section{DAFTAR PUSTAKA}

Arikunto, Suharsimi (2010). Prosedur Penelitian: Suatu Pendekatan Praktik, Jakarta: Rineka Cipta.

Bank Indonesia. 1998. Surat Keputusan Direksi Bank Indonesia No. 30/12/KEP/DIR/1997 tentang Tata Cara Penilaian Tingkat Kesehatan Bank

Umum, Jakarta: Bank Indonesia

Dendawijaya, Lukman (2003), Manajemen Perbankan, Jakarta: Ghalia Indonesia

Martani, Dwi (2015). Akuntansi Keuangan Lanjut 2. Jakarta: Salemba Empat

Payamta dan Doddy Setiawan (2004). Analisis Pengaruh Merger dan Akuisisi terhadap Kinerja Perusahaan Publik di Indonesia: Jurnal Riset Akuntansi Indonesia, Vol 7 No 3

Peraturan Otoritas Jasa Keuangan No. 20/POJK.03./2014 tentang Bank Perkreditan Rakyat. Jakarta: Otoritas Jasa Keuangan.

Peraturan Daerah Provinsi Jawa Tengah No 4 Tahun 2017 tentang Pembentukan Perusahaan Perseoran Daerah Bank Perkreditan Rakyat Badan Kredit Kecamatan Jawa Tengah. Semarang: Pemrov Jawa Tengah

Peraturan Daerah Provinsi Jawa Tengah No 19 Tahun 2002 tentang Perusahaan Daerah Badan Kredit Kecamatan di Propinsi Jawa Tengah. Semarang: Pemrov Jawa Tengah

Prastowo, Dwi (2015), Analisis Laporan Keuangan: Yogyakarta. UPP STIM YKPN 
Syaichu, Muhammad (2006), Merger dan Akuisisi: Alternatif Meningkatkan Kesejahteraan Pemegang Saham, Jurnal Studi Manajemen dan Organisasi, Vol 3 No 2.

Sukhemi. (2007). Evaluasi Kinerja Keuangan Pada PT. Telkom, Tbk. Journal of Accounting \& Economic, 1(1): 21-23

Tulisan Hukum. Peranan Badan Usaha Milik Daerah Sebagai Salah Satu Sumber Pendapatan Daerah. BPK Perwakilan Provinsi Banten

Wijanarko, Hendro (2009). Merger, Akuisisi dan Kinerja Perusahaan (Studi atas Perusahaan Manufaktur yang terdaftar di BEI), UPN Veteran Yogyakarta

Undang-undang Nomor 7 tahun 1992 tentang Perbankan

Undang-undang Nomor 40 tahun 2007 tentang Perseroan Terbatas 